\title{
Gilberto Freyre's Work: Between Urban Morphology and Building Typology - First Approaches
}

\author{
Solange de Aragão ${ }^{1, *}$, André Marques ${ }^{2}$ \\ ${ }^{1}$ Department of Exact Sciences, Nove de Julho University, Brazil \\ ${ }^{2}$ Sao Judas Tadeu University, Brazil
}

Copyright $(2016$ by authors, all rights reserved. Authors agree that this article remains permanently open access under the terms of the Creative Commons Attribution License 4.0 International License.

\begin{abstract}
There are many possible ways of reading Gilberto Freyre's work. One can read them to know about Brazilian society; other to understand the process of mixing races from which resulted Brazilian people; yet some other can do that to get to know the History of Brazil from a sociological point of view. But there is also another possibility which is to find morphological and typological approaches throughout Freyre's work. Since the sociologist adopted the house as the centre of interest of a great part of his works, and analyzed it to comprehend Brazilian society, there is a lot of information in his texts regarding certain types of buildings, as well as information concerning the cities where these buildings were placed. In fact, Gilberto Freyre was one of the first Brazilian researchers who gave attention to the study of the traditional house in relation to the urban landscape it composed. We aim here to present some morphological and typological approaches in Gilberto Freyre's work, considering the trilogy composed by The masters and the slaves, The mansions and the shanties, and Order and Progress, as well as some other important works in which he deals with the theme of the Brazilian house.
\end{abstract}

Keywords Gilberto Freyre's Work, Urban Morphology, Building Typology, The Brazilian House, 19th Century

\section{Introduction}

In general literature, it is possible to find many people who criticize Gilberto Freyre's work. However, reading some of these critical analyzes and then reading the books written by Freyre, anyone will easily find out that many people who criticize them have not read them deeply or not even read them fully. There are still those who misunderstand what Gilberto Freyre really wanted to mean. Therefore, throughout the last decade we have tried to restore to the public in general the value of his work and to demonstrate how was it predecessor of many works that came afterwards. We did it when we wrote Ensaio sobre o jardin (Essay on the Brazilian garden, Solange de Aragão, 2006), which won a special prize from Gilberto Freyre's Foundation, as well as when we wrote Ensaio sobre a casa brasileira do século XIX (Essay on the Brazilian house from the 19th century, Solange de Aragão, 2011). The last one was the result of a post-doctorate research developed at the University of São Paulo, in Brazil. Yet, we do it once more in this article.

During the 1930's, Gilberto Freyre published two of his main works: The masters and the slaves (1933) and The mansions and the shanties (1936). In both of them, he adopted the Brazilian house as the centre of interest of his research on Brazilian society. In both of them, he mentioned the creation and transformation of Brazilian types of buildings, mainly those destined for habitation, analyzing the house produced by a society still in process of formation instead of the house or building projected by renowned architects, as it was ordinary along the 20th century.

Whereas in The masters and the slaves his focus of interest was the rural residence, particularly the sugar-mill complex, in The mansions and the shanties he was interested in the urban house - specially the two up to five-story house which made up some Brazilian urban landscapes at the 19th century. To analyze the house, Freyre considered also the city, or the urban context, with its open and built spaces.

To do his research, Gilberto Freyre made use of some sources such as traveler's writings, biographies, memories, 19th century journals, 19th century photography and pictures, and some other materials that were not vastly considered by Brazilian historians up to then. Therefore, regarding History and History of Architecture, Freyre's work was innovative in the use of these source materials, as well as in that consideration of the common house, which composed the majority of the urban, and the cultural landscape of Brazil. It is necessary to mention that before the sociologist, another writer, Euclides da Cunha, the author of Os sertões (The hinterlands), had based his work on some traveler's writings, although from a very different point of view - and Freyre was aware of such work. It is necessary to 
mention also that Freyre had discovered, read, and published in Portuguese those letters from the engineer Louis Léger Vauthier to César Daly, written at the half of the 19th century, in which the Brazilian house was vastly described in itself and in relation with the environs. Both of them were certainly fundamental to build up Freyre's point of view of the Brazilian nature, landscape, and house. It is necessary to mention either that previously to the writing of these works he had the opportunity of studying in the United States and in Europe, where he would make contact with specialists who were worried about cultural aspects not under consideration in Brazil - which meant an important influence on his work and thought. When he came back to Brazil, he was ready to write several studies on the Brazilian house - in spite of his main objective being the study of Brazilian society.

In his work, Gilberto Freyre studied the master's residence and slave habitation, the two-story house and the "mucambo" (or the shanty), the ground-floor house and the five-story house, and referred also to the chalet, to the garden small palace, and to the country house. In describing them, comparing them, establishing a relationship between them and the landscape, or their surroundings, between them and society, with specific ways of living, he built up a typology of the Brazilian house of the 19th and preceding centuries in the 1930's. Curiously, he was not an architect but a sociologist interested in the study of the house for comprehension of society. Due to this, he would influence many relevant Brazilian historians of architecture, especially at the second half of the 20th century, such as Nestor Goulart Reis Filho and Carlos Lemos.

Always remembered by the everlasting discussion on the advantages of mixed race, Gilberto Freyre should be considered as one of the predecessors of those professionals whose study of the type takes into account society, history and certain morphological aspects.

\section{Morphological and Typological Approaches in Gilberto Freyre's Work}

In Europe, the first studies of the urban form appeared at the end of the 19th century, in works such as those written by Otto Schlüter, who established a morphology of the cultural landscape. In Brazil, the first studies of the urban form may be attributed to some travelers who visited the country during the 19th century whose analysis is more than merely descriptive. Differently from what happened in Europe, it was not the rapid increase of the cities that caught the attention of these travelers, but rather some lack of development in comparison with European civilization as well as their peculiarities such as the fact of their being surrounded by tropical vegetation and their geographical aspects - not to mention cultural, social, historical, economical and architectural differences.

Certainly these studies did not compose a disciplinary field as those oriented by Otto Schlüter and other European geographers; besides, they were written and produced by foreigners; however, they do reveal the 19th century Brazilian city in many aspects even if from an European point of view. Land form, climate, particularities of rivers and vegetation, the arrangement of houses and streets, numbers of floors, building materials, squares, public buildings, all of these characteristics of the 19th century Brazilian city can be found in some traveler's writings. Evidently, we cannot affirm that the totality of them is worthy reading or worthy believing. Some of them were based in previous writings; others do not correspond to reality. However, in comparison with historical data there are some which really are trustworthy. Among them, we could mention works by Saint-Hilaire, Maria Graham, Spix and Martius, Ouseley, John Mawe, and so forth.

In Europe, Schlüter's influence spread out in the middle of the 20th century through Conzen's works (Larkham, 1998). According to this geographer, the urban settlement has the essential attributes of a region and for this reason allows three complementary approaches: the functional, the morphological, and the historical-geographical (Conzen, 2004). In the case of the morphological approach, Conzen emphasizes on the one hand the importance of identification of formative processes and their geographical results in the townscape, and on the other hand, emphasizes the need of close attention to every significant townscape detail (Conzen, 2004).

In Brazil, Conzen's ideas did not spread out until the last decades, but Otto Schlüter has been a renowned geographer in the field of urban geography. Pierre Monbeig and Aroldo de Azevedo were responsible then for introducing, in the 1950 's, the analysis of the urban space in Brazil taking into consideration geographical, historical, social, and cultural aspects.

Concerning typology, in Europe, study of the building type dates back to the epoch of the Industrial Revolution when Jacques Nicolas Durand attempted to classify types of buildings, which made up the architectural pattern from the period. Philippe Panerai defined Durand's typology as analytical since it revealed but basic schemes of building plans and façades (Panerai, 1999). A typology interconnected with urban morphology that evinced relations between building types, the urban context, and the historical period was established in Europe only in the 1950's, when Saverio Muratori founded the Italian school of typology (Moudon, 1998). In the following decade, during the 1960's, Phillipe Panerai and Jean Castex started to develop a new method of typological analysis creating then the French school of typology (Moudon, 1998).

Whereas in Europe geographers were many times responsible for building typology during the 20th century, in Brazil it was Gilberto Freyre, a sociologist, who brought into light the importance of the study of the type for the understanding of man and society. Afterwards were historians of architecture rather than geographers who dedicated their research to the study of building types. 
A considerable difference between building typology in Europe and building typology in Brazil results from this fact. When typology appeared in Brazil, it was intrinsically related to social consideration, as well as to the urban and rural context.

In Gilberto Freyre's work, social, geographical, and cultural aspects are always interconnected. When he studies and analyzes some types of buildings, such as the mansion (or the two or more story houses) and the mucambo (or the shanties), he does it with morphological and typological approaches. He considers house plans, as well as the house in relation to environment, streets, gardens, patios, and the landscape it composes. As a sociologist, Freyre was able to establish a typology of the 19th century Brazilian house with a something of the study of the urban form.

If we take into account European or any other international study of the urban form or of building types, the relevance of Gilberto Freyre's work relies exactly on the importance he gave to social aspects in the study of building types, as well as on his perception of the role of the house in society and in the shaping of man. Freyre believed that this type of architecture - the house - was one of the most important expressions of a culture. As a sociologist, he recognized also the importance of this morphological element in the composition of landscape, especially the cultural landscape.

\section{The Brazilian City in Gilberto Freyre's Work}

In 1960, the Brazilian geographer Aroldo de Azevedo published a text entitled "Gilberto Freyre's work examined by the light of Geography" ("A obra de Gilberto Freyre examinada à luz da Geografia"). In this text, Azevedo draws attention to the important contribution of Gilberto Freyre's work to the field of Geography in Brazil. Azevedo lists some of the main geographical aspects that can be found in Freyre's work such as certain characteristics of the Brazilian environment, or the process of colonization, as well as some relevant aspects concerning the Brazilian city.

In The mansions and the shanties, Freyre presents a study of urban life in Brazil in the 19th century, which has many times a geographical connotation as it includes information on the placement of Brazilian cities, on their urban characteristics, and on their streets, squares and buildings (Azevedo, 1960).

Recife is defined by Freyre as "socially an island and geographically something between an island and a peninsula" (Freyre, 2006a). Differently from what happened in most 19th century Brazilian cities, in Recife there exist flat streets where it was possible to find some four-story houses - a consequence of the geographical characteristic of the place, since there was not much space so that houses could be larger than higher (Freyre, 2006a).

Rio de Janeiro was a city marked by its hills, and this geographical characteristic determined from beginning some social differences and spatial segregation in the urban space. According to Freyre, at first the rich built their houses on the top of the hills, while the poor lived at the bottom of them. Afterwards, the rich left the highest parts of the city to live by the sea, while the poor occupied the hills (Freyre, 2006a).

Regarding the city of Salvador, in Bahia, Freyre observes that it has always been characterized by large and extended streets, with houses open to the sea with plenty of palm trees in their yards (Freyre, 2006a). During the 19th century, the urban landscape of Salvador was also marked by gardens between the houses, mainly in the suburbs where the rich would live (Freyre, 2006a) - once again, it is possible to find a relationship between the type of building and its geographical location in the work of Gilberto Freyre.

When the sociologist takes into consideration the city of São Paulo, he emphasizes how soil type determined building materials during colonial times and in the earlier half of the 19th century, with a predominance of mud walls in urban houses. Besides, he observes how climate influenced architecture as, for instance, in the use of glass windows instead of windows made of wood, due to the rains (Freyre, 2006a). He also affirms that in São Paulo there was a preference for country houses surrounded by gardens and fruit trees to the detriment of urban houses - which partially explains the empty aspect of the city described by 19th century travelers (Freyre, 2006a).

The Brazilian city in Gilberto Freyre's work is considered in its morphological (or geographical) aspects, and these aspects are revealed to explain the way the city was structured - with spatial or social segregation -, to be related with some characteristics of the house itself, and to bring to light characteristics of Brazilian society. In Freyre's work, everything is interconnected: the Brazilian city, the Brazilian society, and their types of buildings.

Some critics would say that these four cities do not represent Brazil as a whole, since there were many other cities at the time. However, these four cities chosen by Freyre were some of the most important cities by then and have deeply influenced many others from South to North, particularly in terms of architecture and urban arrangement, notwithstanding their peculiarities. Therefore, what we do have to keep in mind is that it was not his intention to present some urban analyses but rather demonstrate how architecture and urban space would influence society. In order to do it, he did not have to consider all Brazilian cities when some of them were enough to fulfill his purposes.

\section{Types of Buildings Studied by Gilberto Freyre}

Amongst those houses studied by Gilberto Freyre are the master's residence, slave habitation, the two or more story houses, the ground floor house, the mucambo (or the shanty), and the chalet.

The first one is described at the preface of The masters and the slaves: 
“(...) The sugar-mill master's residence that the colonizer started to build up in Brazil at the 16th century with large mud walls or stone and lime walls, roofed with straw or tiles, a porch in front and beside it, fallen roofs in a maximum of protection against the strongest sun and tropical rain was not a copy of Portuguese houses, but a new expression, corresponding to our physic environment and to an unexpected phase of Portuguese imperialism: their agrarian and sedentary activity in the tropics, their rural and proslavery patriarchy. Since this time the Portuguese (...) became Lusitanian and Brazilian at once, the founder of a new economic and social order; the creator of a new type of habitation. It is enough to compare the floor plan of a 16th century Brazilian house with a 15 th century Lusitanian manor-house to find out the enormous difference between the Portuguese from the reign and the Portuguese from Brazil." (Freyre, 2006b)

The sugar-mill master's residence was a symbol of power in rural areas. Not only slaves but also children and women were under domination of the master inside the limits of his property.

The first master's residences were simple to the point of being roofed with straw. However, throughout the centuries this type of building became more solid being built with less ephemeral materials. Palm trees started then to mark the front garden and the landscape, symbolizing the nobleness of the house and the power of its owner. The patio garden was a mixture of the vegetable garden and the orchard, and presented a meaning of utility much stronger than an aesthetic value, as Gilberto Freyre observed in his second work (Freyre, 2006a).

Inside the master's residence, one could find only the strictly necessary furniture; certain rooms would even appear predominantly empty to the European eye at the beginning of the 19th century. Some chairs here and there, sometimes a table, some other wooden furniture, and it was all that one could find there. Women would sleep in alcoves - bedrooms without windows - away from the eyes of the stranger and under the eye of the master.

The floor plan of the master's residence could be characterized sometimes by a porch between the guest's room and the oratory, a living room after the porch with bedrooms and alcoves on the left and on the right, and a kitchen at the back of the building close to the patio.

The master's residence was part of a complex in rural areas that included slave habitation. The last one was even more rustic than the former. In general, it was a rectangular building with mud walls, roofed with straw or tiles, with small openings, where slaves would sleep. Floor tiles were not used; instead, the ground floor was made of soil. This type of building was in fact a large and rustic room for slaves.

While the master's residence - together with slave habitation - was placed in rural areas, the two or more story houses were situated in the city. They were the richest type of the urban house during the colonial period. As Gilberto

Freyre emphasized, the number of floors as well as building materials were different from place to place. In São Paulo, this type of building used to have two stories and was built with mud walls; in Salvador, Recife and Rio de Janeiro, they were made up of stone or brick and could have three, four or even five story (Freyre, 2006a).

The ground floor of such houses would commonly have rooms for slaves and guests, a store or warehouse, and a narrow corridor that led to the patio. The owner's family would live in fact on the upper floors, where there were rooms and alcoves. Kitchens used to be in the attic, where there were also rooms for female slaves. This kind of arrangement became so usual in the Brazilian house that Vauthier would affirm at the 19th century that those who had seen one of them had seen all of them (Vauthier, 1975).

The two or more story houses were owned by some of the richest people of Brazilian society (from aristocracy and bourgeoisie). They symbolized the most civilized type of habitation in the tropics, according to Freyre:

"There were not a few Brazilians from the first half of the 19th century to whom the good people, the good couple, the family well established, according to the patriarchal orthodoxy, should live, in the city, in a two or more story house, leaving the ground floor house of any sort for those who were socially less consolidated. (...)

This conception - of the two story house still patriarchal and already bourgeois representing the best and highest Brazilian civilization, at the end of the 18 th century and at the beginning of the 19 th century seems to have been general amongst the cultured men of this epoch. Not only Brazilians would have it but also Europeans from the North - almost all of them impregnated with bourgeois and urban notions of civilization." (Freyre, 2006a)

These houses were built side by side on the alignment of narrow lots without front yards (Reis Filho, 1970). Sometimes painted yellow or some other vivid color, they made up some Brazilian urban landscapes up to the 19th century. However, in between one and another building there would almost always be a ground floor house. This was simpler and poorer than the two or more story house. It used to have a store or room at the entrance, followed by one or two alcoves, and a kind of dining room with a kitchen at the back. Many times, it would not present a tiled floor - which would contribute to a great extent to give it a dirty appearance. But however plain it was, this type of building would compose the Brazilian landscape in the same way as the two or more story houses, built up on the alignment of narrow lots. One could say that it was even commoner than the former, mainly within those cities far away from the coast, where European influence was not so deep and commerce was less developed. 

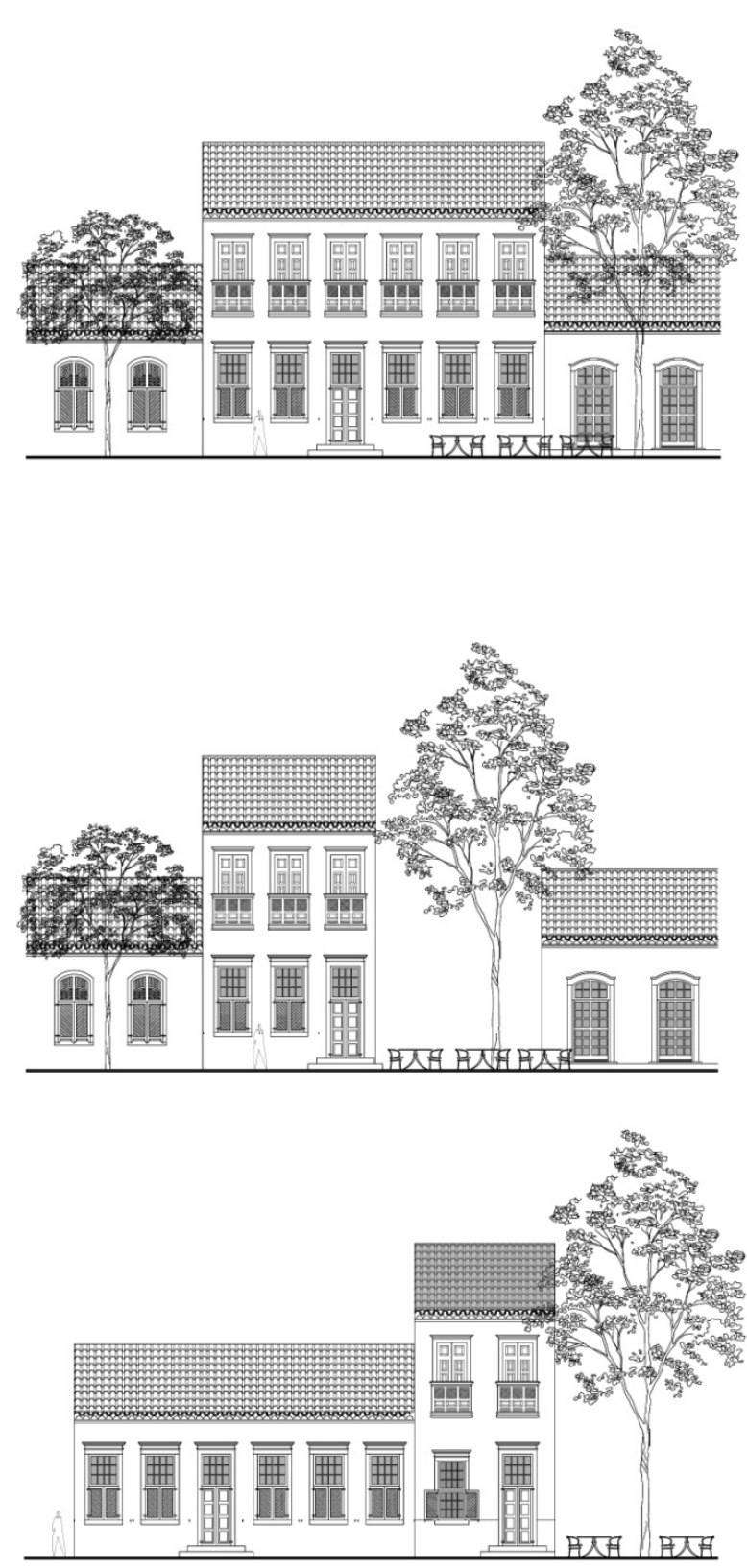

Figure 1. The ground floor and the two story houses built on the alignment of narrow lots. Drawings by André Marques.

Narrow houses built on narrow lots on irregular blocks alongside narrow streets - this was the Brazilian urban morphological pattern during colonial times.

Near the city and sometimes inside of it there was the "mucambo" - one of the poorest types of habitation, but not the worst one concerning some ecological aspects according to Gilberto Freyre (2006a). The "mucambo" was a ground floor house made of straw and stick, and covered with palm leaves, in which it was clear the native and African influence. It was situated in mud flats or in swampy areas - the less valuable areas near the city. The internal arrangement was similar to that of the urban ground floor house, but instead of alcoves, it had bedrooms with windows.

Notwithstanding quality of materials used in this type of building or even the fact of its being an ephemeral house, the "mucambo" was in perfect harmony with the environment. In this sense, it was an ecological type of building, as Freyre emphasizes (FREYRE, 2006a).

In The mansions and the shanties, Gilberto Freyre considered also the chalet, as one of the results of European influence on Brazilian architecture at the 19th century. Whereas in Europe the chalet was a wooden house which could be found in mountainous areas, in Brazil it became a mere style of some urban houses made of brick, characterized by front eaves in contrast with lateral eaves of traditional houses. This type of building used to have a small garden in the front yard - another European influence taking into account that during the colonial period the garden was situated in the backyard or in a patio surrounded by the walls of the residence.

The chalet was also considered in Order and progress (1959). In this book, the sociologist, based on a speech given by Vieira Souto, would express the necessity of a genuine Brazilian architecture to replace certain foreign buildings, such as the chalet that spread throughout Brazilian cities at the end of the 19th century and became common even in commercial streets (Freyre, 2004). In his research, Freyre found out some criticism from the end of the 19th century, which would be common from the second decade of the 20th century on, with Modernism in Brazil. As Vieira Souto, modern architects would recognize the need of a genuine Brazilian architecture, but only some decades afterwards.

In his work, Gilberto Freyre wrote also on the country house, the villas (or small palaces), and the slum tenement. The country house was the best type of residence halfway long the city and rural areas or in the suburbs. It had the advantage of being situated near the city and as well the advantage of being surrounded by nature as the rural residence. Many travelers would emphasize the qualities of the country house and its surroundings such as Robert Burford and W. M. Gore Ouseley:

“(...) The houses in the suburbs are large, more convenient, and abound in the comforts of Europe: they are generally in large gardens, which during a great part of the year resemble huge bouquets (...)." (Burford, 1827)

"The Laranjeiras road is one of those that lead to the ascent of the Corcovado. It follows the widing course of a mountain brook, and the scenery is varied and beautiful. On either side are country houses, cottages, gardens, and 'chacras' or villas, in their enclosed grounds." (Ouseley, 1852)

To the European eye, the country house was a better place for someone to live in than the two-story house within the city. Surrounded by gardens, with a large porch, and many fruit trees throughout its terrain, such ground floor house with oratory, living room, bedrooms and alcoves, and a kitchen at the back, would seem to Europeans more advantageous in aesthetic and hygienic terms than the urban narrow two-story house. 


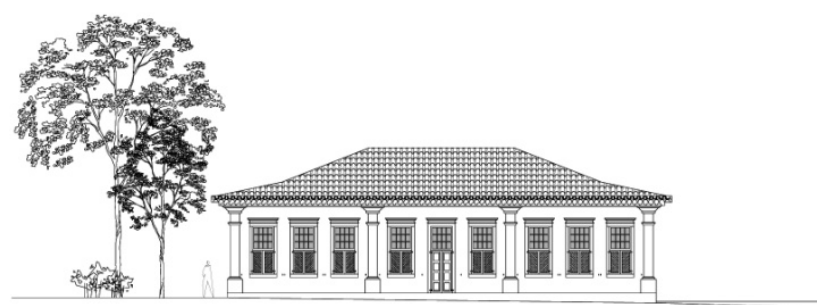

Figure 2. The country house surrounded by gardens. Drawing by André Marques.

The villas or small palaces in the same way as the chalet would be the result of European influence at the end of the 19th century as well as an expression of Eclecticism. According to Freyre, the small palace was many times the residence of the "new-rich", the "new-powers", the "new-intellectual" (Freyre, 2004). It was another type of European building transferred to Brazil, where the social, cultural, and environmental context was very diverse. However, little by little it became one of the urban ways of living of aristocracy and bourgeoisie. Maria Cecília Naclério Homem has defined the small palace as the "type of one-family house, with one or more story, cellar, stylistic accuracy; a detached house, surrounded by gardens, with a service area and an annex at the back" (Homem, 1996).

Inside the residence as outside it, the small palace or villa would express a clear European influence on architecture. Sometimes neoclassical, other times eclectic, its rooms, its furniture, its architectural aesthetics would demonstrate that obsession with everything which was European. Above all, the urban small palace or villa, with its vast garden, would be a symbol of status as the master's residence in rural areas.

While the small palace became the richest type of urban residence, the slum tenement became the poorest one. Carlos Lemos affirmed that the slum tenement was not a house in fact but a group of very small rooms where all the activities would be developed at the same place (Lemos, 1998). The slum tenement was characterized by the worst building materials and by a bathroom and service area common to all residents. It was not a healthy type of building but it was preferred to the "mucambo" by immigrants, and for this reason it became habitation for many industry workers (Freyre, 2006a).

\section{Conclusions}

In The masters and the slaves, The mansions and the shanties, Order and progress, and some other books, Gilberto Freyre brought to light relevant information on the Brazilian house. However, it was in The mansions and the shanties that he decidedly presented a typological study. In this book, he compared the two story urban house with the "mucambo", with the ground floor house, with the country house. He emphasized differences between two story houses from one city to another. He established a relationship between the house and the street and analyzed their transformation at the 19th century under European influence. He established a relationship between the house (or types of houses) and the 19th century Brazilian society - under European influence. He considered the "mucambo" within the environment of which it was part. He established hierarchies, and gave attention to materials, to room arrangements, to open and built spaces. In these terms, it is possible to affirm that he introduced the study of the type in Brazil, more specifically the study of the building type with some morphological connotation, at the moment he wrote and published his second book.

In Gilberto Freyre's work, it is possible to find some information on the Brazilian city and some information on the Brazilian house, but not only this. Freyre's analysis of the Brazilian house as well as of the Brazilian city reveals some typological and morphological approaches with a sociological refinement that is nowadays indispensable for any typological or morphological study.

The reading of European and American texts was fundamental to his consciousness of the importance of the house in man's life, in society, in the urban or the rural landscape. As a sociologist, he looked at the house to understand man and society, but the cultural inheritance from his work goes beyond this. The richness of his work lies not only in the comprehension of Brazilian society, but also in the knowledge of Brazilian houses, Brazilian gardens, Brazilian landscapes. His contribution goes far beyond the sociological field and reaches history of architecture, history, geography, landscape architecture, and so on. His work is certainly of great significance to Brazilian people but also to those who are interested in the way the sociologist analyzes the house considering landscape and society.

\section{REFERENCES}

[1] Azevedo, A. (1958) A cidade de São Paulo (Companhia Editora Nacional, São Paulo).

[2] Azevedo, A. (1958). 'A obra de Gilberto Freyre examinada à luz da Geografia', Boletim Paulista de Geografia 1960, 74-82.

[3] Burford, R. (1827) Description of a view of the city of St. Sebastian, and bay of Rio de Janeiro (1823) (J.And C. Adlard, Bartholomew Close,London).

[4] Conzen, M. R. G. (2004) Thinking about urban form: papers on urban morphology (1932-1998) (Peter Lang, Switzerland).

[5] Freyre, G. (1936) Sobrados e mucambos (Companhia Editora Nacional, São Paulo).

[6] Freyre, G. (2006a) Sobrados e mucambos (Global, São Paulo).

[7] Freyre, G. (2004) Ordem e progresso (Global, São Paulo).

[8] Freyre, G. (2006b) Casa-grande \& senzala (Global, São Paulo).

[9] Homem, M. C. N. (1996) O palacete paulistano e outras 
formas urbanas de morar da elite cafeeira (1867-1918) (Martins Fontes, São Paulo).

[10] Larkham, P. J. 'Urban morphology in the United Kingdom', Typological process and design theory 1998, 159-177 (Massachusetts Institute of Technology, Cambridge).

[11] Lemos, C. (1998) 'Os primeiros cortiços paulistanos'. In: Sampaio, M. R. A. (1998) Habitação e cidade (FAUUSP, Fapesp, São Paulo).

[12] Monbeig, P. (1958) Aspectos geográficos do crescimento de São Paulo (Anhambi, São Paulo).

[13] Moudon, A. V. 'The changing morphology of suburban neighborhoods', Typological process and design theory 1998, 141-157 (Massachusetts Institute of Technology, Cambridge).

[14] Ouseley, W. M. G. (1852) Description of views in South America (Thomas Mc Lean, London).

[15] Panerai, P. (1999)‘Typologies',Analyse urbaine (Éditions Parenthèses, Marseille).

[16] Reis Filho. N. G. (1970) Quadro da arquitetura no Brasil (Perspectiva, São Paulo).

[17] Vauthier, L. L. 'Casas de residência no Brasil'. In: Arquitetura Civil I 1975, 1-94 (FAU-USP, IPHAN, São Paulo). 